Marjorie Biffi*, Pascal Laffaille and Laëtitia Buisson

\title{
Local habitat preferences of a semi-aquatic mammal, the Pyrenean desman Galemys pyrenaicus
}

https://doi.org/10.1515/mammalia-2018-0035

Received February 28, 2018; accepted March 12, 2019; previously published online April 16, 2019

Abstract: To date, the large-scale distribution of the endangered Pyrenean desman, Galemys pyrenaicus, has been related to various abiotic factors (e.g. riverbed and riverbank characteristics, hydrology, topography, climate). However, none could fully explain the recent observed range contraction of the species, suggesting the influence of other drivers. In this study, the potential effect of some unexplored variables on the Pyrenean desman presence was investigated at the local scale (i.e. stream reaches) in the French Pyrenees. They described not only the riverbed, riverbanks, water chemistry, topography and pedology but also the presence of potential interacting species. Generalised linear models were implemented to select the best drivers of the Pyrenean desman presence. Our results stressed the relevance of considering human impacts at the riverbed scale, river narrowing and water chemistry to explain the local distribution of the Pyrenean desman. The presence of two potential competitors, the Eurasian water shrew Neomys fodiens and the dipper Cinclus cinclus, was also highly correlated to the species presence in stream reaches. This suggests that all three species may use the same resources within streams, which could be a potential source of competitive interactions. This study not only highlights the importance of maintaining the riverbed integrity for the Pyrenean desman but also stresses the need to assess the extent to which biotic interactions may affect its distribution in order to understand its current decline.

Keywords: French Pyrenees; habitat use; human impact; stream habitat.

*Corresponding author: Marjorie Biffi, EcoLab, Université de Toulouse, CNRS, Toulouse, France, e-mail: m.biffi@live.fr. https://orcid.org/0000-0001-5006-8001

Pascal Laffaille and Laëtitia Buisson: EcoLab, Université de Toulouse, CNRS, Toulouse, France

\section{Introduction}

For semi-aquatic species, the number of abiotic and biotic potential drivers of communities' structure and species distribution is duplicated as they are closely linked to both aquatic and terrestrial environments (e.g. Greenwood et al. 2002, Mate et al. 2013). In aquatic environments, these organisms need to be adapted to inherent characteristics of water bodies such as geo-morphology, hydrology, water quality or riverbed fine scale features. For instance, river narrowing and stream slope increase hydraulic harshness of rivers by allowing fast responses to rainfall and sudden high flow peaks (Camana et al. 2016). Arvicolids (Mate et al. 2013) and river birds (Royan et al. 2014) have been reported to suffer from drowning and to be impacted by the reduced availability of suitable microhabitats for food and shelters at high flow levels. Water quality is another driver of aquatic and semi-aquatic species distribution and abundance (e.g. Kibichii et al. 2015, Mieza-Paez et al. 2016) with potential direct effects on species physiology (e.g. increased vulnerability to parasites, reduced fertility: Benejam et al. 2010, Peterson and Schulte 2016) and/or indirect effects through their environment (e.g. anoxia, eutrophication: Azevedo et al. 2015) or their prey (Bedford 2009).

Terrestrial environments are used by semi-aquatic species to satisfy their needs in terms of shelters and food resources. For instance, the presence of the Eurasian water shrew Neomys fodiens (Pennant, 1771) or the Southern water vole Arvicola sapidus (Miller, 1908) is favoured in rivers where banks provide existing cavities or the opportunity for digging burrows, respectively (Mate et al. 2013, Keckel et al. 2014). A dense riparian vegetation also provides suitable shelters and refuges to hide from predators. In addition, riparian vegetation may be a direct (i.e. for herbivores) or an indirect (i.e. by hosting terrestrial prey) source of food, which benefits several semi-aquatic mammals (Greenwood et al. 2002, Eubanks et al. 2011, Hysaj et al. 2013, Mate et al. 2013, Speldewinde et al. 2013).

In addition to abiotic factors, biotic interactions are known to be important in explaining species presence in a habitat at different spatial scales (Boulangeat et al. 2012, Kissling et al. 2012, Wisz et al. 2013). It is acknowledged that 
food availability strongly influences the presence and persistence of wildlife populations (Manly et al. 2002) and that competition between species plays a key role in shaping communities (Alexandrou et al. 2011), with consequences on the spatial and temporal use of resources (e.g. niche partitioning: Crow et al. 2010, Cozzi et al. 2012, SánchezHernández et al. 2016). Predator-prey interactions are also important for the conservation of vulnerable species as they may affect the recovery of populations (Mate et al. 2013).

The Pyrenean desman Galemys pyrenaicus (É. Geoffroy Saint-Hilaire, 1811) is a semi-aquatic mammal endemic to the Iberian Peninsula and the Pyrenean Mountains. The species is listed as Vulnerable by the International Union for Conservation of Nature (IUCN) (Fernandes et al. 2008) and is legally protected in the four countries where it is present. Recent local, national and European initiatives (e.g. in France: Némoz et al. 2011, Life + Desman 2013) have given priority to complement the knowledge about its ecology and habitat requirements. Several environmental factors acting both at fine (i.e. riverbed, riverbanks: Biffi et al. 2016) and large (i.e. hydrology, climate, connectivity, topography: Charbonnel et al. 2015, 2016) scales have been recently identified as major drivers shaping the Pyrenean desman distribution in the French Pyrenees. However, none could fully explain the substantial contraction of the species range observed over the past decades (Fernandes et al. 2008, Gisbert and García-Perea 2014, Charbonnel et al. 2016) and its disappearance in several watersheds of the French Pyrenees, suggesting the influence of other and still unknown drivers. Despite this recent enhanced knowledge on the Pyrenean desman ecological preferences, important gaps remain about the potential effect of the water physico-chemistry (i.e. indirect effects on invertebrate prey suggested by Santamarina 1992 and Bertrand 1994), human pressures on the riverbed (e.g. trampling or water abstraction: Lake 2003, Evans et al. 2006, Benejam et al. 2010, Escarpinati et al. 2014) and soil pedology (e.g. indirect effects on invertebrate communities: Kennedy and Fitzmaurice 1971) on the local distribution of the species. Moreover, co-occurrence patterns between the Pyrenean desman and some potential competitors for food resources and habitats (e.g. the dipper Cinclus cinclus (Linnaeus, 1758) and the Eurasian water shrew: Santamarina 1993, Castién and Gosálbez 1999, Biffi et al. 2017b) have been overlooked.

In this context, the aim of this study was to investigate some abiotic and biotic factors that may explain the local distribution of the Pyrenean desman in the French Pyrenees. More specifically, we tested the relative contribution of different categories of variables including riverbank and riverbed descriptors, water quality, topography, pedology, human pressures in the riverbed and the presence of two potential competitors. These variables were chosen either because their influence on the Pyrenean desman has never been tested as far as we are aware, or for comparison purposes because their effect has already been reported (Biffi et al. 2016, Charbonnel et al. 2016).

\section{Materials and methods}

\section{Study area}

The study was conducted in the Ariège department, a French administrative land in the Pyrenees Mountains (Figure 1) where the Pyrenean desman has a high occurrence (Charbonnel et al. 2015, Biffi et al. 2016). The study area is $2885 \mathrm{~km}^{2}$ with a low human density [mean \pm standard deviation (SD): $35 \pm 71$ inhabitants per $\mathrm{km}^{2}$, minimum: 1, maximum: 500; GEOFLAC DB 2016]. It is a mountainous zone (elevation range: 357-3109 m) with a continental climate. The mean annual temperature is $8.7 \pm 2.5^{\circ} \mathrm{C}$ and the mean annual rainfall is $1209.4 \pm 173.0 \mathrm{~mm}$. The land is mainly occupied by natural zones with forests (45.1\%), herbaceous or shrubby vegetation (23.5\%) and agriculture (13.6\%; Corine Land Cover@ DB 2012).

\section{Pyrenean desman, Eurasian water shrew and dipper occurrence records}

Given the cryptic behaviour of the Pyrenean desman, faeces were searched twice between June and September 2015 in 65 sites spread over the entire study area (Figure 1). One site was a 250-m-long river transect where each emergent item of the riverbed (i.e. rock, tree root or branch) was meticulously inspected by skilled observers. This length was chosen as a compromise between high detection rate and reasonable sampling time. It was also in accordance with Aymerich and Gosálbez (2014) who found a high probability of detecting the species when conducting sampling on 200-m-long sections. Sampling was conducted under good and similar environmental conditions for both surveys, excluding periods during or just after (i.e. more than 4 days) fluctuating waters (e.g. rainfall, dam release), and by the same observers, to avoid biasing the detection of Pyrenean desman faeces (Charbonnel et al. 2014). The particularly rainy 2015 summer guaranteed the regular washing of old faeces and the presence of freshly deposited faeces in all sites at the time of sampling.

All putative faeces of the Pyrenean desman as well as those of the Eurasian water shrew were collected based 


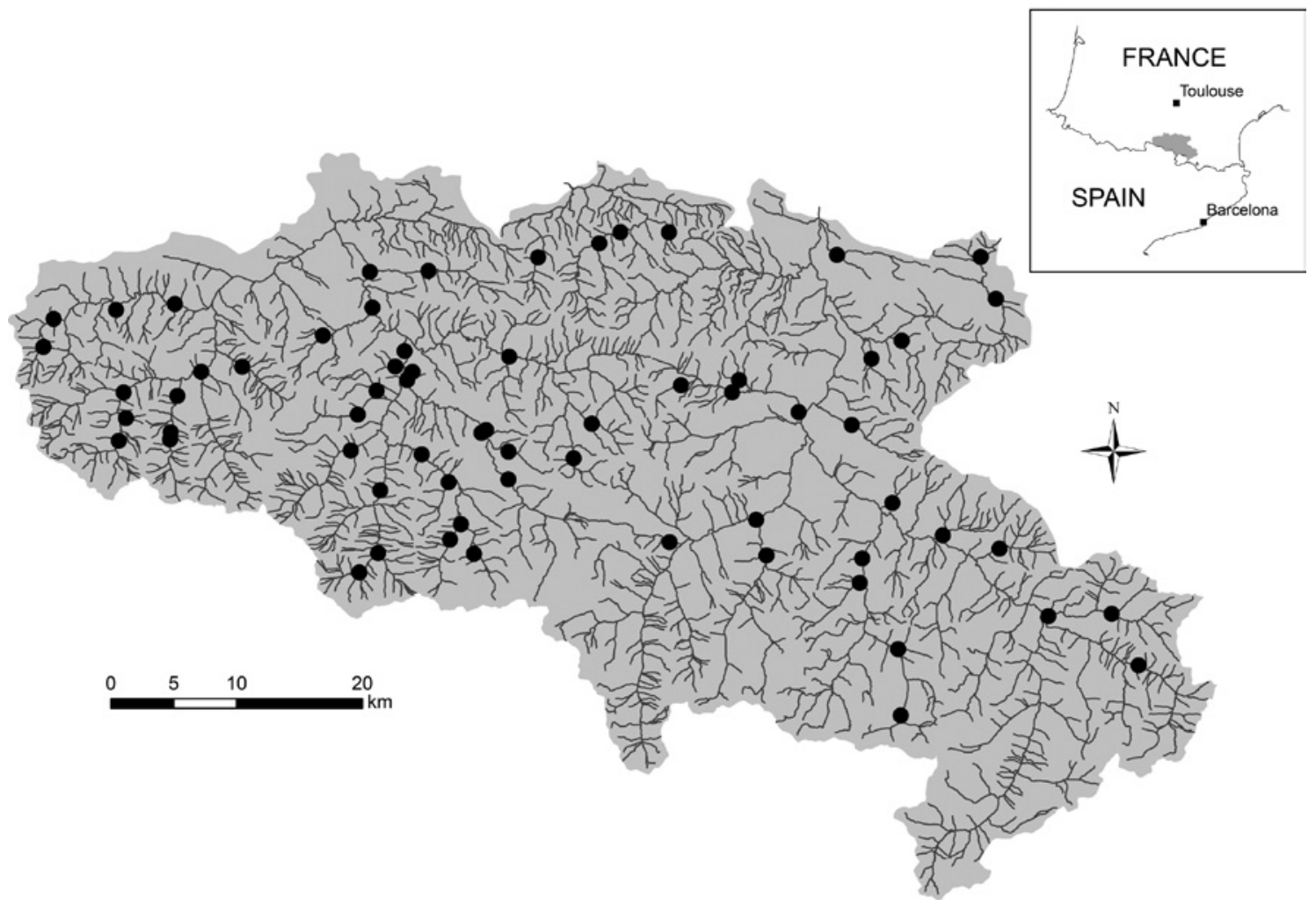

Figure 1: Location of the study area and sampling sites (black dots) in the French Pyrenees.

on their colour, size, smell and position. The search for faeces is an effective protocol for detecting the presence of the Pyrenean desman (Charbonnel et al. 2014) and the Eurasian water shrew which deposits its faeces on similar places (i.e. emerging items near or within the riverbed, Aymerich and Gosálbez 2004). For each faeces, the observer qualitatively assessed the degree of certainty about species identity. Among the faeces collected in each site, a maximum number of seven faeces per mammal species was then selected for further molecular analyses to confirm the presence of species in each site. This number depended on the total number of faeces collected in the site, the degree of certainty in the identification on the field (i.e. more faeces were analysed when it was uncertain) and the freshness and size of the collected faeces (i.e. fresh and large faeces were given priority as molecular analyses are known to perform better than with old and small faeces, McInnes et al. 2017). In addition, the presence of the dipper was recorded during sampling of mammal faeces based on direct observations of the species or indirect presence signs (i.e. pellets).

DNA was extracted from faeces $(n=464)$ using the Stool Mini Kit (Qiagen Inc., Hilden, Germany) and following the instructions from the manufacturer. Polymerase chain reaction (PCR) amplification was duplicated for each sample on a portion of the mitochondrial cytochrome oxidase I gene (COI, for details, see Gillet et al. 2015). The procedure included negative DNA extraction and PCR controls. PCR products were purified and purified amplicons were quantified. The quantification step allowed to pool final products at equimolarity before being sent to the GIGA Genomics platform (University of Liège, Belgium) for sequencing. Raw sequences were sorted and filtered using a script mixing FASTX Toolkit (http://hannonlab. cshl.edu/fastx_toolkit; 23-09-16) and USEARCH (Edgar 2010) functions (see André et al. 2017 for details on bioinformatics). Sequences originating likely from extraction or PCR contaminants were excluded from further analyses. The remaining sequences were compared with the reference online BOLD database for COI (Ratnasingham and Hebert 2007). Sequences that had a unique best-hit were considered to be positive matches with an identity score higher or equal to $99 \%$ for the identification of the species producing the faeces.

\section{Abiotic and biotic variables}

A set of 18 abiotic variables (Table 1) was selected to describe local conditions at the reach scale. They can be 
Table 1: Abiotic and biotic factors expected to influence the abundance of Pyrenean desman faeces in streams.

\begin{tabular}{|c|c|c|}
\hline Category & Code & Description \\
\hline \multirow[t]{5}{*}{ Riverbed } & DEPOS & $\begin{array}{l}\text { Proportion (\%) of the heterogeneity of emerging items (e.g. rocks, trees, roots or branches) and cavities } \\
\text { in the riverbed and riverbanks representing an estimate of the availability of habitats for the semi- } \\
\text { aquatic mammals studied and of deposit areas for faeces. Low proportions indicate a riverbed with } \\
\text { homogeneous substrate and few or no cavities, whereas high proportions indicate a riverbed with a } \\
\text { high diversity of emerging items and cavities }\end{array}$ \\
\hline & CURRENT & $\begin{array}{l}\text { Index of current velocity derived from a principal component analysis (PCA) conducted to summarise } \\
\text { the proportion of six stream facies categories defined according to stream current velocity and depth: } \\
\text { sheet, run, riffle, pool with no current, fast-flowing pool, falls. This index is the first axis of the PCA } \\
\text { summarising } 35.9 \% \text { of the total variability. Small values indicate fast flowing waters }\end{array}$ \\
\hline & GRAINS & $\begin{array}{l}\text { Index of riverbed substrate size derived from a PCA conducted to summarise the proportion of } \\
\text { seven grain-size categories: silt/mud }(<0.05 \mathrm{~mm}) \text {, sand }(0.05-2 \mathrm{~mm}) \text {, gravel }(2 \mathrm{~mm}-2 \mathrm{~cm}) \text {, pebbles } \\
(2-7 \mathrm{~cm}) \text {, cobbles }(7-25 \mathrm{~cm}) \text {, boulders }(25 \mathrm{~cm}-1 \mathrm{~m}) \text {, larger boulders }(>1 \mathrm{~m}) \text {. This index is the first } \\
\text { axis of the PCA summarising } 36.5 \% \text { of the total variability. Small values correspond to the coarsest } \\
\text { grain sizes }\end{array}$ \\
\hline & WIDTH & Mean width of the riverbed (m) \\
\hline & HUMIMP & $\begin{array}{l}\text { Proportion (\%) of the stream reach where a human impact was observed (e.g. presence of fishermen, } \\
\text { cattle, bathers, wastewater discharges, water abstraction) }\end{array}$ \\
\hline \multirow[t]{4}{*}{ Riverbank } & ROOTS & Proportion (\%) of banks with roots \\
\hline & DIRT & Proportion (\%) of banks with bare soil or herbaceous vegetation \\
\hline & HVEG & $\begin{array}{l}\text { Index of vegetation height on the riverbanks derived from a PCA conducted to summarise the } \\
\text { proportion of the riverbanks covered by bare soil, short grasses, tall grasses and shrubby vegetation. } \\
\text { This index is the first axis of the PCA summarising } 43.3 \% \text { of the variability. Small values correspond to } \\
\text { tall vegetation }\end{array}$ \\
\hline & TREE & Proportion (\%) of the riverbanks covered by trees \\
\hline \multirow[t]{5}{*}{ Water chemistry } & DOC & Concentration of dissolved organic carbon $(\mathrm{mg} / \mathrm{l})$ in water \\
\hline & NITRAT & Concentration of nitrate ions $\left(\mathrm{N}-\mathrm{NO}_{3}{ }^{-} \mathrm{mg} / \mathrm{l}\right)$ in water \\
\hline & AMMON & Concentration of ammonium ions $\left(\mathrm{N}-\mathrm{NH}_{4}^{+} \mathrm{mg} / \mathrm{l}\right)$ in water \\
\hline & PHOSPH & Concentration of phosphate ions $\left(\mathrm{P}-\mathrm{PO}_{4}{ }^{3-} \mathrm{mg} / \mathrm{l}\right)$ in water \\
\hline & CONDUC & Water conductivity $(\mu \mathrm{S} / \mathrm{cm})$ \\
\hline \multirow[t]{3}{*}{ Topography } & SLOPE & Mean slope of the river section (\%) \\
\hline & NARROW & $\begin{array}{l}\text { Ratio (\%) of the width of the bottom of the valley divided by the width of the riverbed. Small values } \\
\text { correspond to enclosed streams flowing in a V-shaped valley (e.g. gorges) }\end{array}$ \\
\hline & STRAH & $\begin{array}{l}\text { Stream order as defined by the "top down" system of Strahler (1957) indicating the level of branching } \\
\text { in a river network. Headwater streams at the source are ranked one. When two rivers of the same order } \\
\text { merge, the resulting stream takes one order higher. The higher order number is kept when two rivers } \\
\text { with different order merge }\end{array}$ \\
\hline Pedology & PEDO & Category of soil type in the floodplain: calcareous vs. not calcareous \\
\hline \multirow[t]{2}{*}{ Biotic interactions } & NEOMYS & $\begin{array}{l}\text { Occurrence of the Eurasian water shrew (1: detection vs. } 0 \text { : no detection) validated from molecular } \\
\text { analyses of faeces collected }\end{array}$ \\
\hline & CINCLUS & $\begin{array}{l}\text { Occurrence of the dipper (1: detection vs. } 0 \text { : no detection) from direct observations or detection of } \\
\text { pellets }\end{array}$ \\
\hline
\end{tabular}

grouped into six categories of variables: biotic, riverbed, riverbank, water chemistry, topography and pedology.

Riverbed and riverbank variables were described in the field and computed for each 250-m-stream reach (see Biffi et al. 2016 for more details). Riverbed variables give information on emergent items (DEPOS), flow conditions (CURRENT), riverbed substrate size (GRAINS), mean width of the riverbed (WIDTH) and presence of human impacts (HUMIMP) in the riverbed. Riverbank variables describe the bank composition (i.e. with roots: ROOTS; bare or grassy soil: DIRT) and the riparian vegetation (i.e. index of vegetation height: HVEG; presence of trees: TREE).

The chemistry of stream water was assessed through the sampling of 11 of water collected for each site which was immediately filtered (mesh size: $0.45 \mu \mathrm{m}$ ). Filtered water samples were frozen and analysed using the chemical analytical platform of the EcoLab Laboratory 
(Toulouse, France). The dissolved organic carbon (DOC), nitrates (NITRAT), ammonium (AMMON) and phosphate (PHOSPH) concentrations were measured. The water conductivity (CONDUC) was measured in situ in shallow and non-turbulent fast waters (EUTECH Instruments Série 600 device, Fisher Scientific France, Illkirch, France).

The Strahler stream order (STRAH, Strahler 1957), indicating the location of the sampled site along the upstream-downstream gradient, was derived from the stream network of the study area (CARTHAGEC DB, French database on thematic mapping of the Water Agencies, 2011 version http://www.sandre.eaufrance.fr). It starts at one for headwater tributaries and increases by one when two streams of the same order merge. The narrowness of the river valley (NARROW) and the site slope (SLOPE) were obtained from Valette et al. (2012) and Charbonnel et al. (2016), respectively.

The pedology in the surrounding floodplain soil of each site was obtained from a map of soil landscape units (Guiresse et al. 2014, GIS Sol, https://www.gissol. $\mathrm{fr} /$ ) which are unique in terms of lithology, geomorphology, land use and pedological features. One single variable related to pedology (PEDO) was retained, namely the presence of limestone in the first soil strata, as it is known to affect aquatic species (e.g. Kennedy and Fitzmaurice 1971).

In addition, the occurrence of the Eurasian water shrew (NEOMYS) and the dipper (CINCLUS) was recorded in the sampled sites. The presence of the Mediterranean water shrew, Neomys anomalus (Cabrera, 1907), was detected in nine sites but was not considered for further analyses regarding its marginal presence and its higher use of terrestrial habitats and terrestrial preys compared to the Pyrenean desman and the Eurasian water shrew (Rychlik 1997, Churchfield and Rychlik 2006). As the proportion of putative water shrew faeces genetically confirmed to belong to the Eurasian water shrew (i.e. Neomys fodiens) was low (34\%), only the presence or non-detection of the species confirmed by molecular analyses was considered, and not the number of collected faeces.

\section{Statistical modelling}

A statistical modelling approach was used to assess the relative contribution of the six categories of abiotic and biotic factors on the local distribution of the Pyrenean desman. First, we ensured that the explanatory variables were not highly correlated (Spearman rank correlation $|\mathrm{p}|<0.7$ for all pairs of variables). All quantitative abiotic variables were log-transformed to approach normality, except the variables derived from a principal component analysis (PCA) (i.e. CURRENT, GRAINS, HVEG, Table 1).

Eighty-six percent of putative Pyrenean desman faeces collected and analysed by molecular tools were confirmed to have been produced by the species. Given this high identification rate, the total number of Pyrenean desman faeces counted in each sampled site was used as a surrogate for the intensity of habitat use by the Pyrenean desman. This assumption was based on the study by Nores et al. (1998) in which the density of faeces was much higher in areas where Pyrenean desman individuals were trapped (13.3 faeces per $\mathrm{km}$ ) compared to areas where they were not (3.3 faeces per $\mathrm{km}$ ). The number of Pyrenean desman faeces was thus the response variable in the following statistical modelling.

Generalised linear models (GLMs) were fitted using a quasi-Poisson family distribution for errors and a log-link function as overdispersion was present in the response variable. First, six models were computed for each category of explanatory variables described above (hereafter called "models by category", see Table 1). All models were tested for significance and their explanatory performances were compared using the proportion of explained deviance. Second, an automated model selection procedure was applied to a model including all the 20 selected abiotic and biotic variables (hereafter called "full models"). The quadratic terms of all quantitative variables were also included in models to allow nonmonotonous responses. To reduce the risk of over-fitting due to the small number of observations relative to the number of explanatory variables, the maximum number of explanatory variables included in the candidate models was set to six. This number seems to be a good compromise between the number of observations, the number of explanatory variables and the required computing time. Automated model selection (Calcagno and de Mazancourt 2010) was based on the ranking of Akaike information criterion (AIC) values corrected for small sample size and overdispersed data, QAIC $C_{c}$ (Burnham and Anderson 2002). An exhaustive screening of candidate models and comparison of QAIC $_{c}$ enabled to eliminate the least significant variables (i.e. those which did not reduce the QAIC $_{c}$ of models). Models with $\triangle$ QAIC $_{c}<2$ in comparison with the model with the lowest QAIC value were retained as the best candidate models and tested for significance. The best candidate models were used to calculate the model-averaged relative importance of explanatory variables (Burnham and Anderson 2002) as the sum of Akaike models' weights in which the variable is included, rescaled between 0 and 1 . The Akaike weights and percentages of explained deviance of the 
best models were also used to assess models' explanatory performance.

All statistical analyses were conducted in R 3.3.2 ( $R$ Development Core Team 2014) using the ade4, car and MuMIn packages.

\section{Results}

Among the 464 faeces collected in the 65 sampled sites that were analysed using molecular genetics tools, the presence of the Pyrenean desman and the Eurasian water shrew was confirmed in 58 and 39 sites, respectively. The Pyrenean desman was detected in five sites alone, in 11 sites with the Eurasian water shrew only, in 20 sites with the dipper only and in 22 sites with both species. The number of Pyrenean desman faeces used as the response variable in the statistical models equalled (i) the total number of faeces observed in the field for the 58 sites where the presence of the Pyrenean desman was confirmed by molecular analyses, or (ii) zero in the seven sites where the identity of the Pyrenean desman was not confirmed by molecular tools.

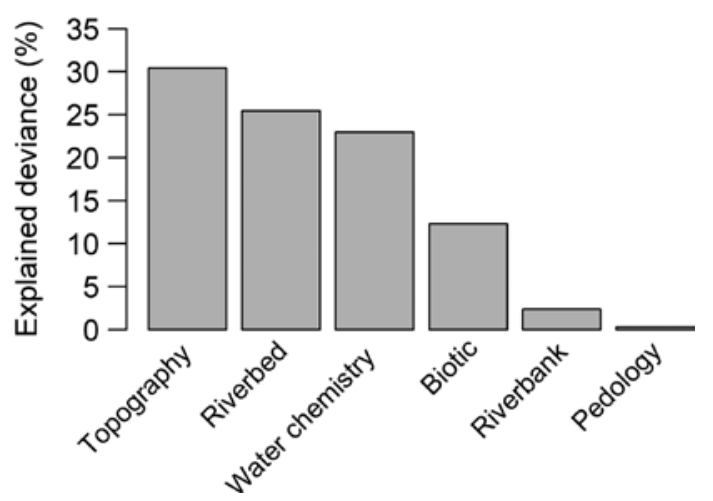

Figure 2: Explanatory power (\% of deviance explained) of GLMs relating the number of Pyrenean desman faeces to a single category of abiotic or biotic variables (“models by category").

See Table 1 for details about the variables belonging to each category.
The number of Pyrenean desman faeces per sampling sites ranged from 0 to 71 (mean: $14 \pm 19$ faeces).

Overall, "models by category" explained between 0.3 and $30.6 \%$ of the total deviance in the number of Pyrenean desman faeces (Figure 2). Variables describing the topography, riverbed and water chemistry explained the highest proportion of deviance in Pyrenean desman faeces abundance while those describing the pedology and riverbank were very poor explanatory factors.

The model selection procedure identified five models as plausible candidates to best explain the abundance of Pyrenean desman faeces according to QAIC $_{c}$ ranking (Table 2). Those models explained between 44.4 and $52.1 \%$ of the variability in the number of Pyrenean desman faeces with Akaike weights between 0.13 and 0.33 (Table 2). Eight variables were selected with different combinations in the five best candidate models. They included one riverbed variable (HUMIMP), three topography variables (NARROW, STRAH, SLOPE), two biotic variables (CINCLUS, NEOMYS) and two water chemistry variables (CONDUC, AMMON). Consistent with the "models by category", the variables describing the riverbanks or pedology were not selected in any of the best candidate models. The relative importance (i.e. sum of Akaike models' weights) of the selected best variables ranged from 0.19 to 1 and was the highest for HUMIMP and NARROW (Table 3).

The influence of HUMIMP and CONDUC was most often non-monotonous and bell-shaped indicating that the number of Pyrenean desman faeces collected was higher at low and intermediate values (Table 3). The negative sign of the estimates for NARROW, the presence of the Eurasian water shrew (NEOMYS 1) and AMMON suggested that these variables were negatively correlated with the number of Pyrenean desman faeces in streams. In contrast, there were more Pyrenean desman faeces detected in streams where the dipper was also detected (CINCLUS 1). The number of Pyrenean desman faeces was the highest in streams with Strahler order equalling two or three (STRAH 2, STRAH 3). Last, the variable SLOPE

Table 2: Best candidate GLMs $\left(\triangle\right.$ QAIC $_{c}<2$ compared to the model with the lowest QAIC $)$ explaining the number of Pyrenean desman faeces in streams.

\begin{tabular}{|c|c|c|c|c|}
\hline Models & QAICC & $\triangle Q A I C C$ & Weights & Explained deviance (\%) \\
\hline AMMON + NEOMYS + HUMIMP + I(HUMIMP^2) + NARROW + STRAH & 85.56 & 0.00 & 0.33 & 52.11 \\
\hline HUMIMP + I(HUMIMP^2) + NARROW + STRAH + CONDUC + I(CONDUC^2) & 86.66 & 1.10 & 0.19 & 50.96 \\
\hline HUMIMP + I(HUMIMP^2)+CONDUC + I(CONDUC^^2)+CINCLUS + SLOPE & 86.71 & 1.15 & 0.19 & 45.14 \\
\hline AMMON + NEOMYS + HUMIMP + I(HUMIMP^2) + NARROW + CINCLUS & 86.97 & 1.40 & 0.16 & 44.87 \\
\hline HUMIMP + I(HUMIMP^2) + NARROW + CONDUC + I(CONDUC^^2)+CINCLUS & 87.45 & 1.88 & 0.13 & 44.37 \\
\hline
\end{tabular}

See Table 1 for details about explanatory variables. ${ }^{\wedge} 2$ is the quadratic term of the variable. 
Table 3: Model-averaged estimates and relative importance of variables computed from the five best candidate GLMs (see Table 2) relating the abundance of Pyrenean desman faeces to abiotic and biotic factors.

\begin{tabular}{|c|c|c|c|c|c|}
\hline Variable & Estimate & SE & p-Value & $\begin{array}{r}\text { Number of models } \\
\text { including the variable }\end{array}$ & $\begin{array}{r}\text { Relative } \\
\text { importance }\end{array}$ \\
\hline HUMIMP & 1.21 & 0.32 & $<0.001$ & 5 & 1.00 \\
\hline $\mathrm{I}\left(\mathrm{HUMIMP}^{\wedge} 2\right)$ & -0.28 & 0.08 & $<0.001$ & 5 & 1.00 \\
\hline NARROW & -0.77 & 0.28 & 0.007 & 4 & 0.81 \\
\hline STRAH 2 & 2.06 & 0.80 & 0.011 & 2 & 0.52 \\
\hline STRAH 3 & 1.61 & 0.81 & 0.050 & 2 & 0.52 \\
\hline STRAH 4 & 0.91 & 0.89 & 0.320 & 2 & 0.52 \\
\hline CONDUC & 4.44 & 2.19 & 0.047 & 3 & 0.51 \\
\hline $\mathrm{I}\left(\mathrm{CONDUC} \mathrm{C}^{\wedge} 2\right)$ & -0.51 & 0.23 & 0.030 & 3 & 0.51 \\
\hline AMMON & -2.00 & 0.69 & 0.004 & 2 & 0.49 \\
\hline NEOMYS 1 & -0.60 & 0.27 & 0.029 & 2 & 0.49 \\
\hline CINCLUS 1 & 1.06 & 0.45 & 0.020 & 3 & 0.48 \\
\hline SLOPE & 0.51 & 0.20 & 0.015 & 1 & 0.19 \\
\hline
\end{tabular}

See Table 1 for details about explanatory variables. ${ }^{\wedge} 2$ is the quadratic term of the variable. SE, standard error.

has the smallest value of relative importance in models (0.19, Table 3), suggesting a limited contribution of this variable to the number of Pyrenean desman faeces at this scale.

\section{Discussion}

In this study, novel categories of abiotic and biotic factors were tested and identified as important in explaining the local distribution of the Pyrenean desman, but with varying intensities. More specifically, these factors allowed identifying environmental conditions that are found in habitats that are lightly (i.e. few faeces) vs. heavily (i.e. many faeces) used by the species. When taken by category, drivers describing the topography, riverbed or water chemistry better explained the number of Pyrenean desman faeces than those describing biotic interactions, riverbanks or pedology. This result was confirmed when combining different categories of variables in a single model as the best candidate models included not only topography, water chemistry and riverbed variables, but also variables describing the biotic environment. This finding suggests that the abundance of Pyrenean desman faeces is likely driven by a mix of abiotic and biotic factors confirming previous studies focusing on other species (e.g. Jo et al. 2017). It is worth noting that the availability in deposit areas for faeces (DEPOS) did not explain the number of Pyrenean desman faeces, suggesting that the potential bias that could have arisen from differences in the availability of depositional areas for faeces between sampled sites was not a confounding factor here.

\section{Novel factors identified as influencing the Pyrenean desman habitat preferences}

To date, the influence of human activities on the Pyrenean desman has only been studied with indirect factors acting at large scale such as the distance to the nearest roads or towns (Barbosa et al. 2009, Williams-Tripp et al. 2012), the proportion of urbanised or agricultural lands (Biffi et al. 2016, Charbonnel et al. 2016), the human population densities near the river and the density of upstream obstacles to water flow (Charbonnel et al. 2016). Although their influence was reported to be contrasted in these previous studies, we found here that human pressures acting at a fine spatial resolution have a significant negative impact on the Pyrenean desman. Indeed, the proportion of human activities in the riverbed, which can be regarded as an index of human impact intensity, is the major driver of the number of collected Pyrenean desman faeces. Despite the highlighted bell-shaped response, the number of faeces starts decreasing when more than $20 \%$ of the site length is impacted by human activities. During faeces sampling, we observed a variety of human impacts including trampling by anglers, bathers and cattle grazing. Trampling likely affects not only the structure of riverbed and riverbanks, but also the diversity, structure and composition of aquatic macroinvertebrate communities, which are the main food resources for the Pyrenean desman (Biffi et al. 2017a). Indeed, trampling results in an increase in the drift of benthic invertebrates and organic matter, as well as in the clogging of the riverbed due to riverbank erosion (Evans et al. 2006, Hardiman and Burgin 2011, Escarpinati et al. 2014). We also observed that the quality of water was affected in some sites by the presence of cattle manure, 
wastewater discharges and water abstraction systems. In a previous study, Biffi et al. (2016) found a lower influence of urban areas within the near floodplain on the presence of the Pyrenean desman. They suggested, as Peyre (1956), that the species may exhibit some tolerance to human disturbances if riverbed and riverbank conditions remain suitable. Thus, our study seems to confirm that all activities directly impacting the riverbed could have an adverse effect on Pyrenean desman populations like the regression observed in the Spanish Pyrenees after a dam release (Aymerich and Gosàlbez 2015). The integrity of riverbed habitats at fine scale is thus an important factor making suitable conditions for the Pyrenean desman in streams.

Contrary to our expectations, a higher number of Pyrenean desman faeces were found in streams flowing in the narrowest valleys. Yet, this typology of streams may favour sudden flooding events that are known to have negative consequences on aquatic and semi-aquatic species (Mate et al. 2013, Royan et al. 2014, Camana et al. 2016). The reported affinity of the Pyrenean desman for streams with numerous tributaries (Charbonnel et al. 2015) may balance this risk because tributaries may act as refuges in case of flooding and are more numerous in the narrowest valleys of the study area. The highlighted preference of the Pyrenean desman for streams flowing in narrow valleys could also result from the negative relationship between narrowness of valleys and human activities as narrower valleys with steep floodplains are less accessible, especially when they are forested, and are thus less exposed to human alterations than wider and flatter lands. Narrow valleys are nevertheless still sensitive to canyoning activities which are known to negatively impact aquatic communities (Hardiman and Burgin 2011). Moreover, narrow valleys prevent sun penetration that may ensure (i) a slower degradation of faeces, for instance, from flushing due to rainfall, and (ii) more stable and colder water temperature (Poole and Berman 2001). Charbonnel et al. (2015) positively related the presence of the Pyrenean desman to colder air temperature and cold-water conditions were considered as important in other studies (Peyre 1956, Richard 1976, Hernandez 1988, Aymerich and Gosálbez 2014). The combination of a better preservation of faeces and more suitable climate conditions for the Pyrenean desman may thus have improved the detection of faeces in the narrowest valleys, explaining that higher faeces abundances were found in these sites.

Water chemistry is an important factor explaining the presence of aquatic species and the composition of communities in streams (Camargo and Alonso 2006, Cheng et al. 2016, Pallottini et al. 2017). In this study, the water conductivity and concentration in ammonium ions were highlighted to have a substantial influence on the local distribution of the Pyrenean desman. The number of Pyrenean desman faeces decreased with increasing ammonium concentration while the response to conductivity was bellshaped peaking at rather low conductivity values $(\approx 100$ $\mu \mathrm{S} / \mathrm{cm})$. The detrimental effects of nitrates on freshwater ecosystems are well known (Vitousek et al. 1997, Camargo and Alonso 2006). Nitrate concentrations are used as indicators of poor water quality with negative influence on otters (Jo et al. 2017). In our study, the sampled sites exhibited small concentration in ammonium (i.e. between 0.1 and $0.2 \mathrm{mg} / \mathrm{l}$ ) that may suggest low potential toxicity risk. Overall, faeces of the Pyrenean desman were more abundant in streams with very limited ion content. Thus, thresholds at which ion concentration starts to negatively affect the species may be lower than for other aquatic species. Based on the current knowledge, it is not possible to ascertain the way water pollution may affect the Pyrenean desman. For instance, pesticide cocktails or medicinal substances are able to cause renal or hepatic pathologies and to affect the growth, behaviour and reproduction cycles of aquatic organisms (e.g. Schwaiger et al. 2004, Kidd et al. 2007, Gandar et al. 2016). The accumulation of pollutants in tissues is also a threat to semi-aquatic mammals (Peterson and Schulte 2016). As the main prey of the Pyrenean desman (i.e. Ephemeroptera, Plecoptera and Trichoptera, Biffi et al. 2017a) is commonly used as an indicator of stream water quality (Usseglio-Polatera et al. 2000, Kibichii et al. 2015), there is an urgent need to investigate the direct (e.g. on biology from DNA to population dynamics) and indirect (e.g. on prey) potential effects of water chemistry on the Pyrenean desman.

Then, we found that two species co-occurring with the Pyrenean desman are significantly related to its local distribution although it was assessed roughly using simple binary variables (presence vs. no detection). The positive relationship between the presence of the dipper and the Pyrenean desman may indicate that a stream suitable for one species also seems to be suitable for the other one (Santamarina and Guitian 1988, Santamarina 1993, Bertrand 1994). However, it is worth noting that the dipper may leave presence signs in habitats that are only punctually crossed during its movements. Such habitats would thus not necessarily suit its ecological requirements but may only represent suitable corridors. By contrast, the selected models highlighted a negative correlation between the presence of the Eurasian water shrew and the number of Pyrenean desman faeces indicating that less Pyrenean desman faeces were detected in streams where the Eurasian water shrew was also present. This finding might suggest a higher competitive interaction between 
these two mammals than with the dipper due to their similar biology, use of similar aquatic and terrestrial habitats and similar food requirements (e.g. trophic resources: Santamarina 1993, Castién and Gosálbez 1999; habitats: Bertrand 1994, Greenwood et al. 2002, Keckel et al. 2014, Biffi et al. 2016). However, an assessment of actual competitive interactions would require the study of both habitat use and diet of the two mammals using the same source of data (e.g. intensity of habitat use or occurrence data) and with a balanced sampling of sites where only one species is present, which was not the case here. In the light of a recent study on the diet of both species (Biffi et al. 2017b), another more likely hypothesis to explain this negative correlation between the two mammals would be that the riverbed conditions suitable for the presence of the Eurasian water shrew may be less suitable for the Pyrenean desman because their use of microhabitats and ecological requirements within streams are different at fine resolution. The Eurasian water shrew is known to be particularly active at the ecotone of stream banks (Lardet 1988) where water flows slowly. It has indeed poor morphological adaptations to aquatic environment (e.g. no palmed feet, Puisségur 1935; short duration of dives, Lardet 1988, Mendes-Soares and Rychlik 2009) that may explain a lower use of habitats with fast current velocities than the Pyrenean desman. To date, the effect of the Eurasian water shrew on the Pyrenean desman, and vice versa, remains unclear and would deserve to be further and more finely investigated.

\section{Remaining uncertainties regarding the Pyrenean desman local habitat preferences}

Despite these original findings contributing to a better understanding of the drivers of the Pyrenean desman local habitat preferences, about half of the variability in the number of the species faeces remained unexplained. First, other abiotic or biotic drivers could be more important in shaping the Pyrenean desman distribution at this local scale than those included in this study. However, a large diversity of abiotic factors has already been explored here and in previous studies (e.g. Charbonnel et al. 2015, 2016, Biffi et al. 2016), suggesting that missing variables would rather correspond to biotic interactions such as predation or the availability of trophic resources. Regarding predation, short-term studies on the introduced American mink Neovison vison (Schreber, 1777) in Spain reported a substantial decrease in the range of the Mediterranean water shrew and the Southern water vole (García-Díaz et al. 2013). Similar observations have been documented in Great Britain on another water vole Arvicola amphibius (Linnaeus, 1758) (Aars et al. 2001). A potential negative impact of the American mink on the Pyrenean desman has been suggested by several authors (Gisbert and García-Perea 2014, Pedroso and Chora 2014, Biffi et al. 2016, Charbonnel et al. 2016) but has never been properly investigated. Regarding trophic resources of the Pyrenean desman, studies on food selectivity and prey availability should also be further documented as the decline of prey in altered conditions may have negative consequences on species that consume them and cause local extinction of populations (Real et al. 2009).

Second, the moderate response of the Pyrenean desman to the high number of abiotic and biotic factors tested here and in previous studies could suggest that this species would be more tolerant to a wide range of environmental conditions than previously thought. However, Charbonnel et al. $(2015,2016)$ reported that the Ariège department, where this study was conducted, is one of the most suitable areas for the Pyrenean desman in the French Pyrenees. In this context, it can be difficult to highlight non-optimal environmental conditions for the species. Thus, stronger responses of the Pyrenean desman to environmental factors would be expected with sampling conducted in both suitable and unsuitable areas where it would occur less frequently.

Third, we used the number of collected faeces as a surrogate for the intensity of habitat use by the Pyrenean desman. Although non-invasive methods such as faeces surveys are commonly used to study species habitat selection, the binary variable they provide (i.e. detection/non-detection of indirect signs of species presence) does not allow to assess the intensity of habitat use (Hull et al. 2016). To date, the habitat selection of the Pyrenean desman had only been studied using presence-absence data (Biffi et al. 2016) or detection histories (Charbonnel et al. 2015, 2016). To overcome this shortcoming, our study relies on the assumption that a higher intensity of habitat use by the Pyrenean desman would imply an increasing number of faeces collected in the field. This higher intensity of habitat use can be regarded in terms of (i) a longer time spent in a site, increasing in turn the probability of depositing faeces, or (ii) a higher abundance of individuals that can produce a higher number of faeces in a short time. This assumption seems reasonable regarding the relatively small home-range of the species (Melero et al. 2012, 2014) and is corroborated by the observations of Nores et al. (1998) in the field where a higher number of faeces were found in sites where the Pyrenean desman was captured compared to sites where it was not. It is however worth noting that habitats where few faeces were found 
may still be valuable to the ecology of the species even if they are less frequently used than others. While many studies have documented a positive relationship between the number of faeces and habitat use for terrestrial species (e.g. Kellner and Swihart 2017), this relationship has been little studied or supported for semi-aquatic species (e.g. for otters: Gallant et al. 2007, Romanowski 2013, Day et al. 2016). Indeed, depositional areas in stream ecosystems are more affected by hydrological fluctuations that may reduce faeces persistence (Ruiz-Olmo and Gosálbez 1997). As faeces deposit behaviour remains poorly understood for the Pyrenean desman, caution should be taken when interpreting our habitat selection results. There is indeed no clue about a potential link between faeces deposit and age, sex, season, abundance of resources or population density. Consequently, further studies are required to clarify if the number of Pyrenean desman faeces is relevant to study its local distribution and ecological requirements at fine resolution. For instance, non-invasive genetic capture-recapture methods (i.e. microsatellite genotyping that allows to individually identify the animal producing the faeces: Lampa et al. 2015, Gillet et al. 2016) could be used to investigate the Pyrenean desman faeces deposit over several seasons in sites where faeces densities are known to be contrasted.

\section{Conclusion and perspectives}

This study not only provides novel insights into the habitat use and selection of the Pyrenean desman but also raises new issues for upcoming research. Our results first stressed the relevance of considering human impacts at the riverbed scale, river narrowness and water chemistry to explain the local distribution and intensity of habitat use by the species. Such variables should thus be targeted for conservation planning of the Pyrenean desman. Based on the highlighted negative influence of human disturbances on the riverbed, the conservation or restoration of the riverbed seems to be one of the major challenges for protecting this endangered species in Pyrenean streams. Not only the impacts of human activities such as canyoning, hydraulic works, bank alterations or trampling by cattle but also people should be further explored as they are known to influence the riverbed structure, aquatic communities and the ecological continuum of rivers (Aparicio et al. 2000, Evans et al. 2006, Hardiman and Burgin 2011, Pedroso et al. 2014). The traditionally used sampling technique for searching faeces (i.e. which consists of wading within the riverbed) could be replaced by less invasive methods such as environmental DNA detection. This method is more and more used for aquatic species (e.g. Rees et al. 2014, Padgett-Stewart et al. 2016) and may overcome the difficulty of detecting the elusive Pyrenean desman with molecular tools used in this study when only degraded DNA is contained in small or old faeces (McInnes et al. 2017).

While the influence of the presence of species sharing the same food and habitats resources as the Pyrenean desman in streams remains unclear, it encourages further studies on this topic. A particular focus on biotic interactions including not only predators (e.g. potential influence of the American mink on the Pyrenean desman range contraction, Barbosa et al. 2009, Gisbert and García-Perea 2014, Pedroso and Chora 2014), competitors, prey (e.g. upward shifts of prey in response to global warming, Domisch et al. 2013) but also parasites and other pathogens (e.g. new emerging diseases affecting amphibians, Skerratt et al. 2007) will be required to fill the remaining gaps in our knowledge of the Pyrenean desman.

Acknowledgements: We are grateful to all people who helped in collecting data in the field and in the laboratory: C. Dupuyds, M. Alvarez., C. Lauzeral, F. Julien, V. Lacaze, S. Lamothe, J. Jabiol, J. Michaux, F. Gillet and A. André. We thank F. Julien and the chemical analytical platform of the EcoLab Laboratory (Toulouse, France) for the data on water chemistry, and E. Cambou and M. Guiresse for their precious help with pedological data. We also thank the "Conservatoire d'Espaces Naturels Midi-Pyrénées" (CEN-MP), especially M. Némoz and F. Blanc, for their precious advice. This study was funded by EDF (Electricité de France) and the European Union (FEDER) in the context of the LIFE + Nature programme devoted to the Pyrenean desman (LIFE13NAT/FR/000092).

\section{References}

Aars, J., X. Lambin, R. Denny and A.C. Griffin. 2001. Water vole in the Scottish uplands: distribution patterns of disturbed and pristine populations ahead and behind the American mink invasion front. Anim. Conserv. 4: 187-194.

Alexandrou, M.A., C. Oliveira, M. Maillard, R.A.R. McGill, J. Newton, S. Creer and M.I. Taylor. 2011. Competition and phylogeny determine community structure in Mullerian co-mimics. Nature 469: 84-88.

André, A., A. Mouton, V. Millien and J. Michaux. 2017. Liver microbiome of Peromyscus leucopus, a key reservoir host species for emerging infectious diseases in North America. Infect. Genet. Evol. 52: 10-18.

Aparicio, E., M.J. Vargas, J.M. Olmo and A. de Sostoa. 2000. Decline of native freshwater fishes in a Mediterranean watershed on the Iberian Peninsula: a quantitative assessment. Environ. Biol. Fishes 59: 11-19. 
Aymerich, P. and J. Gosálbez. 2004. La prospección de excrementos como metodología para el estudio de la distribución de los musgaños (Neomys sp.). Galemys 16: 83-90.

Aymerich, P. and J. Gosálbez. 2014. El desmán ibérico Galemys pyrenaicus (É. Geoffroy Saint-Hilaire, 1811) en los Pirineos meridionales. Munibe Monogr. Nat. Ser. 3: 37-77.

Aymerich, P. and J. Gosálbez. 2015. Evidencias de regresión local del desmán ibérico (Galemys pyrenaicus) en los Pirineos meridionales. Galemys 27: 31-40.

Azevedo, L.B., R. van Zelm, R.S.E.W. Leuven, A.J. Hendriks and M.A.J. Huijbregts. 2015. Combined ecological risks of nitrogen and phosphorus in European freshwaters. Environ. Pollut. 200: 85-92.

Barbosa, A.M., R. Real and J.M. Vargas. 2009. Transferability of environmental favourability models in geographic space: the case of the Iberian desman (Galemys pyrenaicus) in Portugal and Spain. Ecol. Model. 220: 747-754.

Bedford, S.J. 2009. The effects of riparian habitat quality and biological water quality on the European Otter (Lutra lutra) in Devon. Biosci. Horiz. 2: 125-133.

Benejam, L., P.L. Angermeier, A. Munné and E. García-Berthou. 2010. Assessing effects of water abstraction on fish assemblages in Mediterranean streams. Freshw. Biol. 55: 628-642.

Bertrand, A. 1994. Répartition géographique et écologie alimentaire du desman des Pyrénées, Galemys pyrenaicus (Geoffroy, 1811) dans les Pyrénées françaises. Thèse de Doctorat, Université Paul Sabatier, Toulouse, $50 \mathrm{pp}$.

Biffi, M., A. Charbonnel, L. Buisson, F. Blanc, M. Némoz and P. Laffaille. 2016. Spatial differences across the French Pyrenees in the use of local habitat by the endangered semi-aquatic Pyrenean desman (Galemys pyrenaicus). Aquat. Conserv. Mar. Freshw. Ecosyst. 26: 761-774.

Biffi, M., F. Gillet, P. Laffaille, F. Colas, S. Aulagnier, F. Blanc, M. Galan, M.-L. Tiouchichine, M. Némoz, L. Buisson and J.R. Michaux. 2017a. Novel insights into the diet of the Pyrenean desman (Galemys pyrenaicus) using next-generation sequencing molecular analyses. J. Mammal. 98: 1497-1507.

Biffi, M., P. Laffaille, J. Jabiol, A. André, F. Gillet, S. Lamothe, J.R. Michaux and L. Buisson. 2017b. Comparison of diet and prey selectivity of the Pyrenean desman and the Eurasian water shrew using next-generation sequencing methods. Mammal. Biol. 87: 176-184.

Boulangeat, I., D. Gravel and W. Thuiller. 2012. Accounting for dispersal and biotic interactions to disentangle the drivers of species distributions and their abundances. Ecol. Lett. 15: 584-593.

Burnham, K.P. and D.R. Anderson. 2002. Model selection and multimodel inference: a practical information-theoric approach. Springer Verlag. Available at: http://www.springer.com/la/ book/9780387953649 Accessed May 7, 2017.

Calcagno, V. and C. de Mazancourt. 2010. glmulti: an R package for easy automated model selection with (generalized) linear models. J. Stat. Softw. 34: 1-29. Available at: https://www.jstatsoft. org/article/view/v034i12 Accessed May 7, 2017.

Camana, M., R.B. Dala-Corte and F.G. Becker. 2016. Relation between species richness and stream slope in riffle fish assemblages is dependent on spatial scale. Environ. Biol. Fishes 99: 603-612.

Camargo, J.A. and Á. Alonso. 2006. Ecological and toxicological effects of inorganic nitrogen pollution in aquatic ecosystems: a global assessment. Environ. Int. 32: 831-849.
Castién, E. and J. Gosálbez. 1999. Habitat and food preferences in a guild of insectivorous mammals in the Western Pyrenees. Acta Theriol. 44: 1-13.

Charbonnel, A., F. D’Amico, A. Besnard, F. Blanc, L. Buisson, M. Némoz and P. Laffaille. 2014. Spatial replicates as an alternative to temporal replicates for occupancy modelling when surveys are based on linear features of the landscape. J. Appl. Ecol. 51: 1425-1433.

Charbonnel, A., L. Buisson, M. Biffi, F. D’Amico, A. Besnard, S. Aulagnier, F. Blanc, F. Gillet, V. Lacaze, J.R. Michaux, M. Némoz, C. Pagé, J.M. Sanchez-Perez, S. Sauvage and P. Laffaille. 2015. Integrating hydrological features and genetically validated occurrence data in occupancy modelling of an endemic and endangered semi-aquatic mammal, Galemys pyrenaicus, in a Pyrenean catchment. Biol. Conserv. 184: 182-192.

Charbonnel, A., P. Laffaille, M. Biffi, F. Blanc, A. Maire, M. Némoz, J.M. Sanchez-Perez, S. Sauvage and L. Buisson. 2016. Can recent global changes explain the dramatic range contraction of an endangered semi-aquatic mammal species in the French Pyrenees? PLoS One 11: e0159941.

Cheng, S.-T., E.E. Herricks, W.-P. Tsai and F.-J. Chang. 2016. Assessing the natural and anthropogenic influences on basin-wide fish species richness. Sci. Total Environ. 572: 825-836.

Churchfield, S. and L. Rychlik. 2006. Diets and coexistence in Neomys and Sorex shrews in Bialowieza forest, eastern Poland. J. Zool. 269: 381-390.

Corine Land Cover@ DB. 2012. French inventory of land cover of the Ministry of the Environment, 2012 version. https://www.data. gouv.fr/fr/datasets/corine-land-cover-occupation-des-sols-enfrance/.

Cozzi, G., F. Broekhuis, J.W. McNutt, L.A. Turnbull, D.W. Macdonald and B. Schmid. 2012. Fear of the dark or dinner by moonlight? Reduced temporal partitioning among Africa's large carnivores. Ecology 93: 2590-2599.

Crow, S.K., G.P. Closs, J.M. Waters, D.J. Booker and G.P. Wallis. 2010. Niche partitioning and the effect of interspecific competition on microhabitat use by two sympatric galaxiid stream fishes. Freshw. Biol. 55: 967-982.

Day, C.C., M.D. Westover, L.K. Hall, R.T. Larsen and B.R. McMillan. 2016. Comparing direct and indirect methods to estimate detection rates and site use of a cryptic semi-aquatic carnivore. Ecol. Indic. 66: 230-234.

Domisch, S., M.B. Araújo, N. Bonada, S.U. Pauls, S.C. Jähnig and P. Haase. 2013. Modelling distribution in European stream macroinvertebrates under future climates. Glob. Chang. Biol., 19: 752-762.

Edgar, R.C. 2010. Search and clustering orders of magnitude faster than BLAST. Bioinforma. 26: 2460-2461.

Escarpinati, S.C., T. Siqueira, P.B. Jr Medina and F. de Oliveira Roque. 2014. Short-term effects of visitor trampling on macroinvertebrates in karst streams in an ecotourism region. Environ. Monit. Assess. 186: 1655-1663.

Eubanks, B.W., E.C. Hellgren, J.R. Nawrot and R.D. Bluett. 2011. Habitat associations of the marsh rice rat (Oryzomys palustris) in freshwater wetlands of southern Illinois. J. Mammal. 92: 552-560.

Evans, D.J., C.E. Gibson and R.S. Rossell. 2006. Sediment loads and sources in heavily modified Irish catchments: a move towards informed management strategies. Geomorphology 79: 93-113. 
Fernandes, M., J. Herrero, S. Aulagnier and G. Amori. 2008. Galemys pyrenaicus. The IUCN Red List of Threatened Species 2008: e.T8826A12934876. Available at: http://dx.doi.org/10.2305/ IUCN.UK.2008.RLTS.T8826A12934876.en. Accessed June 1, 2014.

Gallant, D., L. Vasseur and C.H. Bérubé. 2007. Unveiling the limitations of scat surveys to monitor social species: a case study on river otters. J. Wildl. Manage. 71: 258-265.

Gandar, A., S. Jean, J. Canal, N. Marty-Gasset, F. Gilbert and P. Laffaille. 2016. Multistress effects on goldfish (Carassius auratus) behavior and metabolism. Environ. Sci. Pollut. Res. 23: 3184-3194.

García-Díaz, P., V. Arévalo, R. Vicente and M. Lizana. 2013. The impact of the American mink (Neovison vison) on native vertebrates in mountainous streams in Central Spain. Eur. J. Wildl. Res. 59: 823-831.

GEOFLA@ DB. 2016. French administrative units of the National Geographical Institute, 2016 version. http://professionnels. ign.fr/donnees.

Gillet, F., M.-L. Tiouchichine, M. Galan, F. Blanc, M. Némoz, S. Aulagnier and J.R. Michaux. 2015. A new method to identify the endangered Pyrenean desman (Galemys pyrenaicus) and to study its diet, using next generation sequencing from faeces. Mammal. Biol. 80: 505-509.

Gillet, F., B. Le Roux, F. Blanc, A. Bodo, C. Fournier-Chambrillon, P. Fournier, F. Jacob, V. Lacaze, M. Némoz, S. Aulagnier and J.R. Michaux. 2016. Genetic monitoring of the endangered Pyrenean desman (Galemys pyrenaicus) in the Aude River, France. Belg. J. Zool. 146: 44-52.

Gisbert, J. and R. García-Perea. 2014. Historia de la regresión del desmán ibérico Galemys pyrenaicus (É. Geoffroy Saint-Hilaire, 1811) en el Sistema Central (Península Ibérica). Munibe Monogr. Nat. Ser. 3: 19-35.

Greenwood, A., S. Churchfield and C. Hickey. 2002. Geographical distribution and habitat occurrence of the water shrew (Neomys fodiens) in the Weald of South-East England. Mammal Rev. 32: 40-50.

Guiresse, M., E. Cambou, C. Collin Bellier, A. Denjean, P. Falba, E. Guigues, M. Mouclier, N. Muller, E. Nesling, J.P. Party, L. Rigou, A. Schneider, A. Toiser, Q. Vauthier, E. Yken and J.C. Revel. 2014. Les pédo-paysages des plaines centrales de MidiPyrénées. Etude Gest. Sols 21: 77-84.

Hardiman, N. and S. Burgin. 2011. Effects of trampling on in-stream macroinvertebrate communities from canyoning activity in the Greater Blue Mountains World Heritage Area. Wetl. Ecol. Manage. 19: 61-71.

Hernandez, A. 1988. Observaciones sobre la distribución, hábitat y comportamiento del topo de río Galemys pyrenaicus Geoffroy, 1811 en el río Torío (León). Misc. Zool. 12: 386-389.

Hull, V., J. Zhang, J. Huang, S. Zhou, A. Viña, A. Shortridge, R. Li, D. Liu, W. Xu, Z. Ouyang, H. Zhang and J. Liu. 2016. Habitat use and selection by giant pandas. PloS One 11: e0162266.

Hysaj, E., F. Bego, C. Prigioni and A. Balestrieri. 2013. Distribution and marking intensity of the Eurasian otter, Lutra lutra, on the River Drinos (southern Albania). Folia Zool. 62: 115-120.

Jo, Y.-S., C.-M. Won, S.R. Fritts, M.C. Wallace and J.T. Baccus. 2017. Distribution and habitat models of the Eurasian otter, Lutra lutra, in South Korea. J. Mammal. 98: 1105-1117.

Keckel, M.R., H. Ansorge and C. Stefen. 2014. Differences in the microhabitat preferences of Neomys fodiens (Pennant 1771) and Neomys anomalus Cabrera, 1907 in Saxony, Germany. Acta Theriol. 59: 485-494.

Kellner, K.F. and R.K. Swihart. 2017. Herbivory on planted oak seedlings across a habitat edge created by timber harvest. Plant Ecol. 218: 213-223.

Kennedy, M. and P. Fitzmaurice. 1971. Growth and food of brown trout Salmo trutta (L.) in Irish waters. Proc. R. Ir. Acad. [B] 71: 269-352.

Kibichii, S., H.B. Feeley, J.-R. Baars and M. Kelly-Quinn. 2015. The influence of water quality on hyporheic invertebrate communities in agricultural catchments. Mar. Freshw. Res. 66: 805-814.

Kidd, K.A., P.J. Blanchfield, K.H. Mills, V.P. Palace, R.E. Evans, J.M. Lazorchak and R.W. Flick. 2007. Collapse of a fish population after exposure to a synthetic estrogen. Proc. Natl. Acad. Sci. 104: 8897-8901.

Kissling, W.D., C.F. Dormann, J. Groeneveld, T. Hickler, I. Kühn, G.J. McInerny, J.M. Montoya, C. Römermann, K. Schiffers, F.M. Schurr, A. Singer, J.-C. Svenning, N.E. Zimmermann and R.B. O’Hara. 2012. Towards novel approaches to modelling biotic interactions in multispecies assemblages at large spatial extents. J. Biogeogr. 39: 2163-2178.

Lake, P.S. 2003. Ecological effects of perturbation by drought in flowing waters. Freshw. Biol. 48: 1161-1172.

Lampa, S., J.-B. Mihoub, B. Gruber, R. Klenke and K. Henle. 2015. Non-invasive genetic mark-recapture as a means to study population sizes and marking behaviour of the elusive Eurasian otter (Lutra lutra). PLoS One 10: e0125684.

Lardet, J.-P. 1988. Spatial behaviour and activity patterns of the water shrew Neomys fodiens in the field. Acta Theriol. 33: 293-303.

Life + Desman 2013. Technical application forms - Conservation of the French populations of Galemys pyrenaicus and its populations on the French Pyrénées, (LIFE13 NAT/FR/000092). 274 pp.

Manly, B.F.J., L.L. McDonald, D.L. Thomas, T.L. McDonald and W.P. Erickson. 2002. Resource selection by animals: statistical design and analysis for field studies. Kluwer Academic Publishers, Dordrecht. $222 \mathrm{pp}$.

Mate, I., J. Barrull, M. Salicrú, J. Ruiz-Olmo and J. Gosálbez. 2013. Habitat selection by Southern water vole (Arvicola sapidus) in riparian environments of Mediterranean mountain areas: a conservation tool for the species. Acta Theriol. 58: 25-37.

McInnes, J.C., R. Alderman, B.E. Deagle, M.-A. Lea, B. Raymond and S.N. Jarman. 2017. Optimised scat collection protocols for dietary DNA metabarcoding in vertebrates. Methods Ecol. Evol. 8: 192-202.

Melero, Y., P. Aymerich, J.J. Luque-Larena and J. Gosálbez. 2012. New insights into social and space use behaviour of the endangered Pyrenean desman (Galemys pyrenaicus). Eur. J. Wildl. Res. 58: 185-193.

Melero, Y., P. Aymerich, G. Santulli and J. Gosálbez. 2014. Activity and space patterns of Pyrenean desman (Galemys pyrenaicus) suggest non-aggressive and non-territorial behaviour. Eur. J. Wildl. Res. 60: 707-715.

Mendes-Soares, H. and L. Rychlik. 2009. Differences in swimming and diving abilities between two sympatric species of water shrews: Neomys anomalus and Neomys fodiens (Soricidae). J. Ethol. 27: 317-325.

Mieza-Paez, E., D. Martínez-Martínez, A. Tarragó, A.S. Sanz and J.N. Vera. 2016. Current situation and environmental factors affecting the distribution of Emys orbicularis in Sèquia Major (NE 
Iberian Peninsula) in syntopy with Mauremys leprosa. Basic appl. Herpetol. 30: 47-59.

Némoz, M., A. Bertrand, M. Sourie and P. Arlot. 2011. A French conservation action plan for the Pyrenean desman Galemys pyrenaicus. Galemys 23: 47-50.

Nores, C., F. Ojeda, A. Ruano, I. Villate, J. González, J.M. Cano and E. García. 1998. Estimating the population density of Galemys pyrenaicus in four Spanish rivers. J. Zool. 246: 454-457.

Padgett-Stewart, T.M., T.M. Wilcox, K.J. Carim, K.S. McKelvey, M.K. Young and M.K. Schwartz. 2016. An eDNA assay for river otter detection: a tool for surveying a semi-aquatic mammal. Conserv. Genet. Resour. 8: 5-7.

Pallottini, M., D. Cappelletti, A. Fabrizi, E. Gaino, E. Goretti, R. Selvaggi and R. Céréghino. 2017. Macroinvertebrate functional trait responses to chemical pollution in agricultural-industrial landscapes. River Res. Appl. 33: 505-513.

Pedroso, N.M. and S. Chora. 2014. The Iberian desman Galemys pyrenaicus (E. Geoffroy Saint-Hilaire, 1811) in Portugal: status and conservation. Munibe Monogr. Nat. Ser. 3: 13-18.

Pedroso, N.M., T.A. Marques and M. Santos-Reis. 2014. The response of otters to environmental changes imposed by the construction of large dams. Aquat. Conserv. Mar. Freshw. Ecosyst. 24: 66-80.

Peterson, E.K. and B.A. Schulte. 2016. Impacts of pollutants on beavers and otters with implications for ecosystem ramifications. J. Contemp. Water Res. Educ. 157: 33-45.

Peyre, A. 1956. Ecologie et biogéographie du Desman (Galemys pyrenaicus) dans les Pyrénées françaises. Mammalia 20: 405-418.

Poole, G.C. and C.H. Berman. 2001. An ecological perspective on in-stream temperature: natural heat dynamics and mechanisms of human-caused thermal degradation. Environ. Manage. 27: 787-802.

Puisségur, C. 1935. Recherches sur le Desman des Pyrénées. Bull. Soc. Hist. nat. Toulouse. 67: 163-227.

R Development Core Team. 2014. R: a language and environment for statistical computing. R Foundation for Statistical Computing, Vienna, Austria. Available at: http://www.R-project.org. Accessed April 16, 2016.

Ratnasingham, S. and P.D.N. Hebert. 2007. BOLD: the barcode of life data system (http://www.barcodinglife.org). Mol. Ecol. Notes 7: 355-364.

Real, R., A.M. Barbosa, A. Rodríguez, F.J. García, J.M. Vargas, L.J. Palomo and M. Delibes. 2009. Conservation biogeography of ecologically interacting species: the case of the Iberian lynx and the European rabbit. Divers. Distrib. 15: 390-400.

Rees, H.C., B.C. Maddison, D.J. Middleditch, J.R.M. Patmore and K.C. Gough. 2014. The detection of aquatic animal species using environmental DNA - a review of eDNA as a survey tool in ecology. J. Appl. Ecol. 51: 1450-1459.

Richard, P.B. 1976. Extension en France du Desman des Pyrénées (Galemys pyrenaicus) et son environnement. Bull. Ecol. 7: 327-334.

Romanowski, J. 2013. Detection of otter (Lutra lutra l.) signs in a survey of central and eastern Poland: methodological implications. Pol. J. Ecol. 61: 597-604.

Royan, A., D.M. Hannah, S.J. Reynolds, D.G. Noble and J.P. Sadler. 2014. River birds' response to hydrological extremes: new vulnerability index and conservation implications. Biol. Conserv. 177: 64-73.

Ruiz-Olmo, J. and J. Gosálbez. 1997. Observations on the sprainting behaviour of the otter Lutra lutra in the NE Spain. Acta Theriol. 42: 259-270.
Rychlik, L. 1997. Differences in foraging behaviour between water shrews: Neomys anomalus and Neomys fodiens. Acta Theriol. 42: 351-386.

Sánchez-Hernández, J., H.-M. Gabler and P.-A. Amundsen. 2016. Food resource partitioning between stream-dwelling Arctic charr Salvelinus alpinus (L.), Atlantic salmon Salmo salar L. and alpine bullhead Cottus poecilopus Heckel, 1836: an example of water column segregation. Hydrobiologia 783: 105-115.

Santamarina, J. 1992. Trophic resources of Galemys pyrenaicus (Geoffroy, 1811) in relation with water quality. In: Proceedings of the meeting on the Pyrenean desman, Lisbon. 28 Sept./1 Oct. pp. 27-32.

Santamarina, J. 1993. Feeding ecology of a vertebrate assemblage inhabiting a stream of NW Spain (Riobo; Ulla basin). Hydrobiologia 252: 175-191.

Santamarina, J. and J. Guitian. 1988. Quelques données sur le régime alimentaire du Desman (Galemys pyrenaicus) dans le nord-ouest de l'Espagne. Mammalia 52: 302-307.

Schwaiger, J., H. Ferling, U. Mallow, H. Wintermayr and R.D. Negele. 2004. Toxic effects of the non-steroidal antiinflammatory drug diclofenac. Part I: histopathological alterations and bioaccumulation in rainbow trout. Aquat. Toxicol. 68: 141-150.

Skerratt, L.F., L. Berger, R. Speare, S. Cashins, K.R. McDonald, A.D. Phillott, H.B. Hines, and N. Kenyon. 2007. Spread of Chytridiomycosis has caused the rapid global decline and extinction of frogs. EcoHealth. 4: 125.

Speldewinde, P.C., P. Close, M. Weybury and S. Comer. 2013. Habitat preference of the Australian water rat (Hydromys chrysogaster) in a coastal wetland and stream, Two Peoples Bay, south-western Australia. Aust. Mammal. 35: 188-194.

Strahler, A.N. 1957. Quantitative analysis of watershed geomorphology. Eos Trans. Am. Geophys. Union 38: 913-920.

Usseglio-Polatera, P., M. Bournaud, P. Richoux and H. Tachet. 2000. Biological and ecological traits of benthic freshwater macroinvertebrates: relationships and definition of groups with similar traits. Freshw. Biol. 43: 175-205.

Valette, L., J. Piffady, A. Chandesris and Y. Souchon. 2012. SYRAHCE : Description des données et modélisation du risque d'altération de l'hydromorphologie des cours d'eau pour l'Etat des lieux DCE. Rapport final, Pôle Hydroécologie des cours d'eau Onema-Irstea Lyon, MALY-LHQ, Lyon, 104 pp.

Vitousek, P.M., J.D. Aber, R.W. Howarth, G.E. Likens, P.A. Matson, D.W. Schindler, W.H. Schlesinger and D.G. Tilman. 1997. Human alteration of the global nitrogen cycle: sources and consequences. Ecol. Appl. 7: 737-750.

Williams-Tripp, M., F. D’Amico, C. Pagé, A. Bertrand, M. Némoz and J.A. Brown. 2012. Modeling rare species distribution at the edge: the case for the vulnerable endemic Pyrenean desman in France. Sci. World J. 2012: Article ID 612965 (6 pages).

Wisz, M.S., J. Pottier, W.D. Kissling, L. Pellissier, J. Lenoir, C.F. Damgaard, C.F. Dormann, M.C. Forchhammer, J.-A. Grytnes, A. Guisan, R.K. Heikkinen, T.T. Høye, I. Kühn, M. Luoto, L. Maiorano, M.-C. Nilsson, S. Normand, E. Öckinger, N.M. Schmidt, M. Termansen, A. Timmermann, D.A. Wardle, P. Aastrup and J.-C. Svenning. 2013. The role of biotic interactions in shaping distributions and realised assemblages of species: implications for species distribution modelling. Biol. Rev. 88: 15-30. 